\title{
Analisis Efektivitas Insulin Analog dan Human yang Digunakan pada Penderita Diabetes Melitus Tipe-2 dengan Biaya BPJS di RS. Islam Sukapura 2018
}

\author{
Muhammad Zaim*, Purwantyastuti, Nafrialdi \\ Departemen Farmakologi dan Terapeutik, Fakultas Kedokteran Universitas Indonesia, Indonesia \\ *Corresponding author: aimzaim81@yahoo.com
}

\begin{abstract}
Background: Insulin is a type-2 diabetes mellitus drug mainly used in patients who are unresponsive to oral drugs. There are 2 groups of insulin, namely analog insulin and human insulin. The optimal treatment strategy for patients is given oral antidiabetics. If the HbAlc level is $>7 \%$, insulin or oral antidiabetic monotherapy can be given. Purposes: The aim of this study was to compare the effectiveness of treatment using analog insulin and human insulin in Islam Sukapura Hospital in the period January - December 2018. Methods: This study is a retrospective study based on the medical records of type-2 diabetes mellitus patients who were treated at the internal disease polyclinic of Islamic Hospital Sukapura in the January-December 2018 period. The statistical test used was the mann-whitney test and chi-square test. Results: From the 200 patients, 82 received human insulin and the average difference between the initial and final HbAlc was $1.40 \%$. In the 118 patients receiving analog insulin, the mean difference between baseline and final HbAlc was 1.34\%. There was no statistically significant difference between the mean difference between baseline and late HbAlc in patients receiving human insulin and insulin analogues $(P=0.785)$. Side effects of insulin were found, such as hypoglycemia of $3.5 \%$ which can occur with long-term insulin administration and in large doses. Conclusion: There is no statistically or clinically significant difference in the effectiveness of human insulin compared to analog insulin.
\end{abstract}

Keywords: analog insulin, effectiveness, human insulin, pharmacoeconomics, type-2 diabetes mellitus

\begin{abstract}
ABSTRAK
Latar Belakang: Insulin merupakan obat diabetes melitus tipe-2 terutama digunakan pada pasien yang sudah tidak responsif dengan obat oral. Dikenal 2 kelompok insulin yaitu insulin analog dan insulin human. Strategi pengobatan optimal untuk pasien diberikan antidiabetik oral. Apabila kadar HbA1c > 7\%, dapat diberikan insulin atau antidiabetik oral monoterapi Tujuan: Tujuan penelitian ini adalah membandingkan efektifitas pengobatan menggunakan obat insulin analog dan insulin human di RS. Islam Sukapura dalam periode JanuariDesember 2018. Metode: Studi retrospektif ini dilakukan berdasarkan rekam medis pasien diabetes melitus tipe-2 yang berobat di poliklinik penyakit dalam RS.Islam Sukapura dalam periode Januari-Desember 2018. Uji statistic yang digunakan yaitu uji beda mann-whitney dan uji chi-square. Hasil: Dari 200 pasien terdapat 82 orang yang mendapatkan insulin human dan rata-rata selisih HbA1c awal dan akhir sebesar 1,40\%. Pada 118 pasien yang mendapatkan insulin analog, rata-rata selisih HbA1c awal dan akhir sebesar 1,34 \%. Secara statistik tidak terdapat perbedaan bermakna antara rerata selisih HbA1c awal dan akhir pasien yang mendapatkan insulin human dan insulin analog $(\mathrm{P}=0,785)$. Efek samping insulin yang ditemukan seperti hipoglikemia sebesar 3,5\% yang dapat terjadi pada pemberian Insulin dalam jangka waktu lama dan pada dosis yang besar. Simpulan: Tidak ada perbedaan yang
\end{abstract}


bermakna secara statistik maupun klinik efektifitas insulin human dibandingkan insulin analog.

Kata kunci: diabetes melitus tipe-2, effectiveness, farmakoekonomi, insulin analog, insulin human

\section{PENDAHULUAN}

Penelitian - penelitian epidemiologi menunjukkan adanya kecenderungan peningkatan angka insidens dan prevalensi diabetes melitus di berbagai penjuru dunia. WHO memprediksi adanya peningkatan jumlah pasien diabetes melitus yang cukup besar untuk tahun-tahun mendatang. WHO memprediksi kenaikan jumlah pasien diabetes melitus di Indonesia meningkat yaitu dari 5,7\% pada tahun 2007 menjadi 6,9 \% pada tahun 2013 (1). Berdasarkan hasil Riset kesehatan dasar tahun 2013 prevalensi penderita diabetes mellitus di Indonesia sebesar 6,9\%, TGT sebesar $29,9 \%$, GDP terganggu sebesar 36,6\%. Jika estimasi jumlah penduduk Indonesia usia 15 tahun ke atas pada tahun 2013 sebesar 176.689.336 orang, maka diperkirakan jumlah absolut penderita diabetes melitus sekitar 12.191.564 orang, TGT sekitar 52.830.111 orang, dan GDP terganggu sekitar 64.668.297 orang (2).

Berdasarkan data Badan Pusat Statistik Indonesia (2013) diperkirakan penduduk Indonesia yang berusia di atas 20 tahun adalah sebesar 133 juta jiwa, dengan prevalensi diabetes melitus pada daerah urban sebesar $14,7 \%$ dan daerah rural sebesar 7,2\%. Diperkirakan pada tahun 2030 terdapat pasien diabetes melitus sejumlah 8,2 juta di daerah urban dan 5,5 juta di daerah rural. Jumlah ini yang sangat besar dan merupakan beban yang sangat berat untuk dapat ditangani sendiri oleh dokter spesialis/subspesialis bahkan oleh semua tenaga kesehatan yang ada, mengingat bahwa diabetes melitus akan memberikan dampak terhadap kualitas sumber daya manusia dan peningkatan biaya kesehatan yang cukup besar, baik di masyarakat maupun di pemerintah (3).

Menurut Baynest (2015), klasifikasi diabetes melitus terdiri dari diabetes melitus tipe-2 yang disebabkan kerusakan sel beta, umumnya menjurus ke defisiensi insulin absolut. Kerusakan sel beta pada diabetes melitus tipe-2 disebabkan penyakit autoimun atau idiopatik. Diabetes melitus tipe-2 mempunyai karakteristik terdapat anti-glutamic acid decarboxylase, islet cell atau insulin antibody terdapat dalam proses autoimun yang menyebabkan kerusakan sel beta pancreas (4). Patofisiologi pada diabetes melitus tipe-2 yaitu terdapat kerusakan pada sel beta pankreas dan resistensi insulin pada otot dan hati. Kekurangan insulin dapat merusak otot, hati dan juga organ lain seperti pada jaringan lemak terjadi lipolysis, gastrointestinal terjadi defisiensi incretin, sel alpha pancreas terjadi hiperglikemia, ginjal terjadi peningkatan absorpsi glukosa dan otak terjadi resistensi insulin, hal tersebut dapat menimbulkan terjadinya diabetes melitus tipe-2 (5).

Pada patofisiologi diabetes melitus tipe-2 terdapat organ - organ tubuh yang mempengaruhinya yaitu terjadinya kegagalan sel beta pankreas. Kegagalan sel beta pankreas dapat mengakibatkan produksi insulin berkurang sehingga glukosa tidak dapat dirubah menjadi glikogen. Contoh obat antidiabetik yang bekerja melalui jalur ini ialah Sulfonilurea, meglitinide, GLP-1 agonis dan DPP inhibitor. Di dalam hati terjadi gangguan 
sehingga terjadi resistensi insulin yang berat dan menyebabkan terjadinya glukoneogenesis pada pasien diabetes melitus tipe-2 sehingga produksi glukosa dalam keadaan basal di dalam hati (HGP=hepatic glucoseproduction) meningkat. Contoh obat yang bekerja melalui jalur ini ialah metformin, cara kerja metformin ialah menekan gluconeogenesis (6). Gangguan kinerja insulin yang multiple di intramioselular pada pasien diabetes melitus tipe-2 yang mengakibatkan gangguan fosforilasi tirosin sehingga timbul gangguan transport glukosa dalam sel otot, penurunan sintesis glikogen dan penurunan oksidasi glukosa. Di dalam sel lemak yang mengalami resistensi terhadap efek antilipolisis dari insulin, menyebabkan peningkatan proses lipolisis dan kadar asam lemak bebas (FFA=Free Faty Acid) dalam plasma.

Peningkatan FFA akan menyebabkan proses glukoneogenesis dan resistensi insulin di liver dan otot. Sehingga FFA dapat menyebabkan terjadinya gangguan sekresi insulin (7). Di dalam usus ada efek yang dikenal sebagai efek incretin, ada 2 hormon yang berperan ialah GLP-1 (glucagon-like polypeptide 1) dan GIP (gluocose-dependent insulinotropic polypeptide). Defisiensi GLP-1 dan resisten terhadap GIP terdapat pada pasien diabetes melitus tipe-2. Incretin segera dipecah oleh keberadaan enzim DPP-4 sehingga hanya bekerja dalam beberapa menit. Sel $-\alpha$ berfungsi dalam sintesis glukagon yang dalam keadaan puasa kadarnya di dalam plasma akan meningkat. Peningkatan ini menyebabkan HGP dalam keadaan basal meningkat secara signifikan dibanding individu yang normal (8).

Menurut E. Mannuci tahun 2009 bahwa penggunaan insulin analog dalam menurunkan kadar $\mathrm{HbA1c}$ dan kadar glukosa postprandial dibandingkan penggunaan insulin human tidak berbeda secara significant. Penggunaan insulin analog dibandingkan penggunaan insulin human dalam menurunkan kadar HbA1c dan kadar glukosa postprandial tidak ada perbedaan yang bermakna dalam pengobataan diabetes mellitus (9). Menurut American Association of Clinical Endocrinologist tahun 2015 bahwa indikasi insulin yaitu bila HbA1c>9\% dengan kondisi dekompensasi metabolik, penurunan berat badan yang cepat, terjadi hiperglikemia berat yang disertai ketosis, terjadi krisis hiperglikemia, gagal dengan kombinasi $\mathrm{OHO}$ dosis optimal dan gagal dengan insulin human, stress berat (infeksi sistemik, operasi besar, infark miokard akut, stroke) kehamilan dengan diabetes melitus/diabetes melitus gestasional yang tidak terkendali dengan perencanaan makan, gangguan fungsi ginjal atau hati yang berat, kontraindikasi atau alergi terhadap $\mathrm{OHO}$, kondisi perioperatif sesuai dengan indikasi.

Pada pasien diabetes melitus tipe-2 pemberian insulin dapat menimbulkan efek samping seperti hipoglikemia, obesitas, lipodistropi, osteoporosis dan reaksi alergi terhadap insulin, tetapi efek samping ini jarang terjadi (10). Pada pasien diabetes melitus tipe-2 yang diberikan insulin dapat terjadi efek samping, saran yang dapat diberikan kepada pasien diabetes melitus tipe-2 ialah penyesuaian dosis basal untuk pasien rawat jalan dapat dilakukan menambah 2-4 unit setiap 3-4 hari bila sasaran belum tercapai. Apabila sasaran glukosa darah basal (puasa) telah tercapai, sedangkan HbA1c belum mencapai target, maka dilakukan pengendalian glukosa darah prandial (meal-related).

Insulin yang dipergunakan untuk mencapai sasaran glukosa darah prandial 
adalah insulin kerja cepat (rapid acting) yang disuntikan 5-10 menit sebelum makan atau insulin kerja pendek (short acting) yang disuntikkan 30 menit sebelum makan. Pemberian insulin basal juga dapat dikombinasikan dengan obat antihiperglikemik oral untuk menurunkan glukosa darah prandial seperti golongan obat peningkat sekresi insulin kerja pendek (golongan glinid) atau penghambat penyerapan karbohidrat dari lumen usus (acarbose) atau metformin (golongan biguanid). Pada terapi insulin tunggal atau kombinasi disesuaikan dengan kebutuhan pasien dan respon individu yang dinilai dari hasil pemeriksaan kadar glukosa darah harian. Menurut Algorithm Insulin Analog American Diabetes Association tahun 2018 bahwa pemberian insulin pertama kali diberikan sebagai basal insulin. Basal insulin yang diberikan yaitu insulin human. Insulin human yang diberikan yaitu short acting dan intermediate acting sesuai dosis yang dibutuhkan pasien diabetes melitus.

Banyak pasien diabetes melitus tipe2 yang membutuhkan manfaat dari insulin. Pasien diabetes melitus tipe-2 harus teratur berobat dan patuh minum obat. Dokter harus menghindari menggunakan insulin sebagai ancaman sehingga pasien jadi tidak mau untuk menggunakan insulin. Algorithm insulin analog dapat digunakan untuk pemberian dosis insulin berdasarkan pemantauan peningkatan kadar glukosa darah pada penderita diabetes melitus tipe2. Pemberian edukasi yang menyeluruh tentang pemantauan kadar glukosa darah, diet, dan pencegahan untuk terjadinya hipoglikemi dalam memberikan insulin (11).

Basal insulin sendiri ialah regimen yang mudah diberikan dengan insulin dimulai 10 unit per hari atau 0,1-0,2 units $/ \mathrm{kg} / \mathrm{hari}$, tergantung tingkat hyperglycemia. Basal insulin biasanya diresepkan dengan metformin ditambah satu obat antihiperglikemik yang bukan insulin pada pasien Diabetes melitus tipe2, Long acting basal analog (U-100 gargline or detemir) dapat digunakan NPH untuk mengurangi resiko simptomatik dan nokturnal hipoglikemia. Longer acting basal analogs (U-300 gargline or degludec) dapat menurukan resiko hipoglikemia dibandingkan U-100 glargine yang dikombinasi dengan obat antihiperglikemik. Ada bukti ilmiah untuk menurunkan hipoglikemia dengan longer acting basal insulin analog, pasien dengan riwayat hipoglikemia dapat diturunkan resikonya dengan mengganti insulin analog menjadi insulin human.

Harga insulin analog yang mahal, penggunaan insulin human merupakan pilihan yang terbaik untuk pasien dan dokter klinis yang biasa menggunakannya. Pasien Diabetes membutuhkan bolus dosis insulin diberikan pada waktu makan ditambah basal insulin. Insulin yang diberikan ialah Rapid acting analog, Pemberian Rapid acting analog karena onset kerja yang cepat setelah pemberian dosis. Di bulan September 2017, FDA telah setuju dengan formulasi Faster acting dari insulin aspart. Dosis yang direkomendasikan pada saat makan ialah 4 unit, 0,1 unit $/ \mathrm{kg}$ or $10 \%$ dari dosis basal. Jika A1C $<8 \% \quad(64 \mathrm{mmol} / \mathrm{mol})$ ketika memulai bolus insulin pada saat makan pertimbangan diberikan untuk menurunkan dosis basal insulin. Tujuan umum penelitian ini adalah menilai Effektivitas insulin analog dibandingkan insulin human pada pasien diabetes melitus yang dibiayai dengan dana BPJS. Tujuan khusus penelitian ini mendapatkan prevalensi pasien DM tipe-2 yang menggunakan 
insulin analog dan insulin human di RS Islam Sukapura dalam periode Januari 2018 - Desember 2018. Membandingkan tingkat keberhasilan pengendalian gula darah antara insulin analog dan insulin human di RS. ISLAM SUKAPURA dalam periode Januari 2018 - Desember 2018.

\section{METODE}

Penelitian ini merupakan penelitian observasional yang dilakukan secara retrospektif terhadap pasien dengan diagnosis diabetes melitus tipe-2 di Poliklinik rawat jalan Penyakit Dalam Rumah Sakit Islam Sukapura Jakarta. Analisis farmakoekonomi dilakukan berdasarkan keluaran klinis yang terdiri dari kemanfaatan klinis (effectiveness). Kemanfaatan klinis dinilai berdasarkan pengunaan insulin analog dan insulin human yang mengakibatkan penurunan kadar HbA1c pada pasien diabetes melitus di poliklinik rawat jalan Penyakit Dalam Rumah Sakit Islam Sukapura Jakarta.

Pada penelitian ini data dikumpulkan untuk mendapatkan nilai HbAlc pasien yang menggunakan obat insulin analog dan insulin human pada pasien-pasien diabetes melitus tipe-2 di Poliklinik Penyakit Dalam RS. Islam Sukapura selama kurun waktu Januari Desember 2018, sehingga dapat menentukan manfaat bila menggunakan obat insulin human dibandingkan insulin analog. Variabel independen pada penelitian ini, yaitu pemberian insulin analog dan insulin human, sedangkan variabel dependen penelitian ini, yaitu kadar HbA1c. Data penelitian diambil dari rekam medik pasien-pasien diabetes melitus tipe-2 yang diberikan insulin analog dan insulin human di Poliklinik Penyakit Dalam RS. Islam Sukapura selama periode 1 Januari - 31 Desember 2018. Kriteria inklusi pada penelitian ini ialah pasien usia $\geq 18$ tahun, pasien yang didiagnosis diabetes melitus tipe-2, pasien yang mendapat terapi insulin, pasien yang diperiksa HBA1c, difollow-up selama 3 bulan dan diperiksa kembali HbA1c. Kriteria eksklusi pada penelitian ini yaitu data rekam medik yang tidak diperiksa $\mathrm{HbAlc}$, pasien yang didiagnosis diabetes melitus dengan hipertensi, pasien yang di diagnosis diabetes melitus dengan penyakit jantung koroner, pasien yang di diagnosis diabetes melitus dengan gagal ginjal. Data sekunder diambil dari rekam medis pasien diabetes melitus yang mendapat terapi insulin di Poliklinik Penyakit Dalam RS. Islam Sukapura periode Januari 2018 - Desember 2018. Jumlah populasi yang akan diteliti ialah 200 orang. Terdapat kelompok diabetes melitus tipe-2 terkontrol jika $(\mathrm{HbA} 1 \mathrm{c}<7)$ dan tidak terkontrol jika (HbA1c > 7). Dari 200 orang yang diteliti didapatkan 82 pasien mendapat Insulin Human dan 118 pasien mendapat Insulin Analog. Uji statistik yang digunakan adalah uji beda menggunakan uji Mannwhitney dan uji Chi-square melalui software statistik SPSS. Penelitian ini telah mendapatkan keterangan lolos kaji etik dari Komisi Etik Penelitian Kesehatan Fakultas Kedokteran Universitas Indonesia dengan nomor: 0784/UN2.F1/ETIK/2018.

\section{HASIL}

Pada penelitian ini terdapat 200 orang subjek penelitian yang merupakan pasien diabetes melitus tipe-2 yang mendapatkan pengobatan Insulin Human dan Insulin Analog. Dari 200 orang, terdapat 82 orang mendapatkan pengobatan Insulin Human dan 118 orang mendapatkan pengobatan Insulin Analog di Poliklinik Penyakit Dalam RS. Islam Sukapura periode Januari 2018-Desember 2018.

Dari tabel 1 dapat dilihat antara rata-rata usia pada kedua kelompok pengguna insulin tidak berbeda bermakna $(\mathrm{P}=0,221)$ dengan uji $\mathrm{T}$ Test. Pada tabel 2 terdapat pola distribusi 
yang berbeda bermakna antara jenis kelamin pasien diabetes melitus yang diberikan insulin human dibandingkan pasien yang diberikan insulin analog. Setelah dilakukan uji statistik dengan uji Chi Square didapatkan hasil $(\mathrm{P}=0,000)$.

Tabel 1. Usia Subjek Penelitian

\begin{tabular}{lccc}
\hline Karakterisik & $\begin{array}{c}\text { Insulin } \\
\text { Human } \\
\mathbf{n = 8 2}\end{array}$ & $\begin{array}{c}\text { Insulin } \\
\text { Analog } \\
\mathbf{n = 1 1 8}\end{array}$ & $\begin{array}{c}\mathbf{P} \\
\text { Value }\end{array}$ \\
\hline $\begin{array}{l}\text { Usia } \\
\text { Mean } \pm\end{array}$ & $57,07 \pm 8,80$ & $55,66 \pm 7,39$ & 0,221 \\
SD) & & & \\
\hline
\end{tabular}

Tabel 2. Jenis Kelamin Subjek Penelitian

\begin{tabular}{lccc}
\hline Karakterisik & $\begin{array}{c}\text { Insulin } \\
\text { Human } \\
\mathbf{n = 8 2} \\
\mathbf{n}(\boldsymbol{\%})\end{array}$ & $\begin{array}{c}\text { Insulin } \\
\text { Analog } \\
\mathbf{n = 1 1 8} \\
\mathbf{n ( \% )}\end{array}$ & $\begin{array}{c}\mathbf{P} \\
\text { Value }\end{array}$ \\
\hline Jenis Kelamin & & \\
Laki - Laki & $47(56)$ & $37(44)$ & 0,000 \\
Perempuan & $35(30,2)$ & $81(69,8)$ & 0,000 \\
\hline
\end{tabular}

Analisis manfaat penggunaan insulin pada pasien diabetes melitus:

Tabel 3. Perubahan HbA1c pasien diabetes melitus dengan insulin

\begin{tabular}{lccc}
\hline & $\begin{array}{c}\text { Insulin } \\
\text { Human } \\
\mathbf{n = 8 2}\end{array}$ & $\begin{array}{c}\text { Insulin } \\
\text { Analog } \\
\mathbf{n = 1 1 8}\end{array}$ & $\begin{array}{c}\mathbf{P} \\
\text { Value }\end{array}$ \\
\hline HbA1c Awal & $9,35 \pm$ & $9,33 \pm$ & 0,785 \\
& 0,801 & 0,896 & \\
HbA1c Akhir & $7,94 \pm$ & $7,98 \pm$ & 0,875 \\
& 0,813 & 0.935 & \\
$\Delta$ HbA1c & $1,40 \pm$ & $1,34 \pm$ & 0,802 \\
& 0,620 & 0,543 & \\
\hline
\end{tabular}

Pada tabel 3, rata-rata $\mathrm{HbA1c}$ awal pasien yang diberikan insulin human dibandingkan insulin analog tidak berbeda bermakna (uji Mann Whitney $(\mathrm{P}=0,785)$ ). Rata-rata HbA1c akhir pasien yang diberikan insulin human dibandingkan insulin analog tidak berbeda bermakna (Mann Whitney $(\mathrm{P}=0,875)$ ). Rata-rata selisih HbA1c awal dan akhir pasien yang diberikan insulin human dibandingkan insulin analog tidak berbeda bermakna (uji Mann Whitney $(\mathrm{P}=0,802)$ ).

Tabel 4. Diabetes mellitus terkontrol/tidak

\begin{tabular}{lccc}
\hline & $\begin{array}{c}\text { Insulin } \\
\text { Human } \\
\mathbf{n = 8 2} \\
\mathbf{n}(\%)\end{array}$ & $\begin{array}{c}\text { Insulin } \\
\text { Analog } \\
\mathbf{n = 1 1 8} \\
\mathbf{n}(\%)\end{array}$ & $\begin{array}{c}\mathbf{P} \\
\text { Value }\end{array}$ \\
\hline Terkontrol & & & \\
Iya & $25(30,49)$ & $43(36,44)$ & 0,382 \\
Tidak & $57(69,51)$ & $75(63,56)$ & 0,382 \\
\hline Keterangan : & & \\
1. Terkontrol jika $(\mathrm{HbA1c}<7)$ \\
2. Tidak terkontrol jika $(\mathrm{HbA1c}>7)$
\end{tabular}

Dari tabel 4 terlihat tidak ada perbedaan bermakna antara pasien diabetes melitus tipe2 yang diberikan insulin human dan insulin analog dalam hal terkontrol atau tidak terkontrol setelah dilakukan Chi Square $(\mathrm{P}=0,382)$.

Tabel 5. Kejadian Hipoglikemi pada pasien yang mendapat insulin analog dan insulin human

\begin{tabular}{lccc}
\hline & $\begin{array}{c}\text { Insulin } \\
\text { Human } \\
\mathbf{n = 8 2} \\
\mathbf{n}(\%)\end{array}$ & $\begin{array}{c}\text { Insulin } \\
\text { Analog } \\
\mathbf{n = 1 1 8} \\
\mathbf{n}(\%)\end{array}$ & $\begin{array}{c}\mathbf{P} \\
\text { Value }\end{array}$ \\
\hline \multicolumn{2}{l}{ Hipoglikemia } & & \\
Iya & $3(3,65)$ & $4(3,39)$ & 0,919 \\
Tidak & $79(96,35)$ & $114(96,61)$ & \\
\hline
\end{tabular}

Dari tabel 5 dapat diihat tidak ada perbedaan yang bermakna secara statistik antara pasien diabetes melitus yang diberikan insulin human yang mengalami hipoglikemia dan tidak hipoglikemia dibandingkan pasien diabetes melitus yang diberikan insulin analog setelah dilakukan Chi Square $(\mathrm{P}=0,919)$.

\section{PEMBAHASAN}

\section{Karakteristik subjek penelitian}

Pada penelitian ini pasien diabetes melitus tipe-2 dengan jenis kelamin perempuan lebih dominan dari laki-laki yaitu masing-masing perempuan 116 orang (58\%) dan laki-laki 84 
orang (42\%). Jumlah usia (50-60 tahun) lebih banyak dibandingkan (usia 30-40 tahun). Pada penelitian Jorge Enrique, dkk. Dari 313 pasien Diabetes melitus 56,9 \% terdiri dari perempuan dengan rata-rata umur 57 tahun (12). Pada Penelitian Szalat Auryan, dkk bahwa perempuan (55\%) menderita Diabetes melitus dibandingkan laki-laki (45\%) karena pada perempuan mengalami penurunan estrogen yang menyebabkan terjadinya resistensi insulin dan gangguan metabolisme glukosa (13). Menurut Riskesdas tahun 2013 proporsi penderita Diabetes melitus di Indonesia sebesar 6,9 \%. Jika estimasi penduduk usia di atas 15 tahun pada tahun 2013 sebesar 176.689.336 orang, maka diperkirakan jumlah absolut penderita Diabetes melitus sebesar 12.191.564 orang. Terdapat persamaan dengan penelitian ini yaitu jumlah penderita Diabetes melitus lebih banyak sebesar 200 orang dan rata-rata usia penderita Diabetes melitus pada penelitian ini sebesar 57,07 \pm 8,80tahun yang diberikan insulin human dan 55,66 \pm 7,39 tahun yang diberikan insulin analog (14).

Menurut algorithm insulin Kaiser Permante Nasional Guideline Thailand tahun 2015 bahwa pengobatan Diabetes melitus tipe-2 di mulai dengan pemeriksaan HbA1c, bila $\mathrm{HbA1c}$ belum memenuhi target HbA1c (7-8\%) dapat diberikan metformin dengan dosis awal $250 \mathrm{mg} 1 \mathrm{x}$ sehari dan dosis terapetik $1000 \mathrm{mg} /$ hari atau $850 \mathrm{mg} /$ hari. Bila HbA1c belum memenuhi target dapat diberikan insulin basal dengan dosis awal 12 Unit sebelum tidur. Untuk dosis terapi, dosis ditingkatkan saat tidur diberikan NPH human insulin diberikan 4 Unit sampai kadar glukosa darah puasa $<120 \mathrm{mg} / \mathrm{dL}$ dan diberikan Glimepiride dengan dosis awal 1-2 mg 1x sehari (1mg 1x sehari untuk lansia). Untuk dosis terapetik dosisnya 1-8 mg $1 \mathrm{x}$ sehari (15).
Menurut European Assosiation for study of Diabetes tahun 2015 Pemberian kombinasi injeksi terapi dimulai dengan basal insulin yaitu insulin human, yang diberikan ialah reguler human insulin dan reguler NPH atau reguler pre-mixed formulation. Dosis di mulai 10 Unit/hari atau 0,1 atau 0,2/ $\mathrm{kgbb} / \mathrm{hari}$. Dapat diatur dosisnya menjadi 10$15 \%$ atau 2-4 unit, 1-2 kali seminggu untuk mencapai target glukosa darah puasa. Untuk hipolikemia dosis diturunkan menjadi 4 unit atau 10-20\%. Jika target glukosa darah belum tercapai dapat ditambahkan 1 kali injeksi rapid insulin sebelum makan besar. Dosis Injeksi rapid insulin dimulai 4 unit atau 0,1 Unit/kgbb, atau $10 \%$ basal dosis. Jika HbA1c $<8 \%$ dosis basal insulin dapat diturunkan. Dosis dapat diatur dengan meningkatkan dosis 1-2 unit atau 10-15\% 1-2 kali seminggu sampai target kadar glukosa terpenuhi. Untuk Hipoglikemia dapat diturunkan dosisnya 2-4 unit atau 10-20\%. Apabila glukosa darah belum terkontrol $\geq 2$ kali injeksi rapid insulin sebelum makan (basal bolus) (16).

Menurut algorithm insulin Malaysian Endocrine of metabolic society tahun 2015 bahwa pengobatan Diabetes melitus tipe-2 di mulai dengan pemeriksaan $\mathrm{HbA1c}$, bila kadar HbA1c $<10 \%$ atau kadar glukosa puasa $>13$ mmol/L, bila kadar HbAlc > 8\% diberikan basal insulin dimulai dengan insulin prandial dan basal insulin. Insulin yang diberikan ialah insulin human (Short acting insulin dan Intermediate insulin). Bila $\mathrm{HbA1c}<9 \%$ dapat diberikan bolus insulin ( prandial insulin pada saat sebelum makan, dan basal insulin sebelum tidur) dengan dosis optimum (17).

\section{Efektifitas kedua jenis insulin pada subjek penelitian}

Pada penelitian ini dari 200 pasien terdapat 82 orang yang mendapatkan insulin human dan rata-rata selisih $\mathrm{HbA1c}$ awal dan akhir 
sebesar 1,40 \%. Pada 118 pasien yang mendapatkan insulin analog, rata-rata selisih HbA1c awal dan akhir sebesar 1,34\%. Secara statistik tidak terdapat perbedaan bermakna antara rata-rata selisih $\mathrm{HbAlc}$ awal dan akhir pasien yang mendapatkan insulin human dan insulin analog $(\mathrm{P}=0,785)$.

Pada penelitian ini pengobatan diabetes melitus tipe-2 di poliklinik penyakit dalam RS.Islam Sukapura, pertama kali diberikan pengetahuan dan pendidikan mengenai perubahan pola hidup, kemudian dilanjutkan dengan pemberian obat antihiperglikemik oral seperti metformin atau glibenklamid. Pemberian antihiperglikemik oral diberikan dengan monoterapi, Apabila kadar HbAlc < 9\% dapat diberikan antihiperglikemik oral Dual therapi. Apabila kadar HbA1c > $9 \%$ dapat diberikan antihiperglikemik oral Triple Therapi. Apabila kadar HbA1c > 9\% dapat diberikan insulin Kombinasi Injeksi Terapi. Pemberian injeksi Insulin pertama kali yaitu diberikan injeksi insulin analog. Pemberian basal insulin analog (Long acting insulin) diberikan dengan dosis 0,1-0,2 unit/kg/hari, pemberian basal insulin analog (Long acting insulin) diberikan setiap 8 jam. Apabila kadar HbAlc > 9\% dapat diberikan Rapid acting insulin sebelum makan besar dengan dosis 0,1 U/kg dan diberikan setiap 6 jam. Perbandingan antara penelitian ini dan Algorithm Insulin ADA tahun 2018 ialah pada penelitian ini pasien Diabetes melitus tipe-2 diberikan basal insulin pertama kali dengan insulin analog (Long acting insulin) sedangkan di Algorithm Insulin ADA tahun 2018 pertama kali pemberian insulin diberikan insulin human (Short acting insulin). Menurut ADA tahun 2018 bahwa insulin analog efektifitasnya sama dengan insulin human. Perbedaan antara insulin analog dan insulin human ialah insulin analog lebih mahal dibandingkan insulin human. Pada penelitian ini pemberian insulin analog dipoliklinik penyakit dalam RS. Islam Sukapura dinilai kurang tepat karena pemberian insulin analog mempunyai kekurangan yaitu efektifitas insulin analog dan insulin human sama, harga insulin analog lebih mahal dibandingkan insulin human. Dapat disarankan ke poliklinik penyakit dalam RS. Islam Sukapura untuk menggunakan insulin human karena mempunyai keuntungan insulin human harganya lebih murah dan efektifitasnya sama dengan insulin analog.

\section{Efek samping obat insulin pada subjek penelitian}

Menurut Hye Jin Yu, dkk bahwa pada pasien Diabetes tipe-2 penggunaan insulin analog dibandingkan insulin human, resiko terjadinya Hipoglikemia yang diberikan insulin analog dapat diturunkan $47 \%(\mathrm{P}<0,001)$ dan yang diberikan insulin human dapat diturunkan $55 \%(\mathrm{P}<0,001)$. Dibandingkan dengan penelitian ini terdapat persamaan yaitu angka kejadian Hipoglikemia lebih kecil pada pasien Diabetes melitus yang diberikan insulin analog dan insulin human (18). Pada penelitian ini pasien Diabetes melitus yang diberikan insulin dan menimbulkan efek samping obat seperti Hipoglikemia sebesar 3 orang $(3,65)$ pada kelompok yang diberikan insulin human dan 4 orang $(3,39 \%)$ pada kelompok yang diberikan insulin analog. Menurut Siqne Borgquist tahun 2018 bahwa pemberian insulin jangka panjang dapat menimbulkan kanker payudara. Penggunaan insulin jangka panjang dapat meningkatkan pertumbuhan kanker payudara dan meningkatkan efek sinyal mitogenik melalui insulin reseptor isoform A dan insulin-like growth factor 1 (IGF-1) reseptor atau secara tidak langsung melalui sirkulasi estrogen. Efek potensial karsinogenik diperlihatkan secara in vitro dengan peningkatan pertumbuhan sel epitel payudara manusia dan sel kanker paryudara. Meskipun secara in vitro berhubungan 
dengan dan menjadi fokus ialah resiko pemberian insulin jangka panjang dari luar tubuh dan peningkatan kadar insulin di sirkulasi darah manusia (19).

\section{SIMPULAN}

Penelitian ini membandingkan manfaat penggunaan insulin human dan insulin analog pada penderita diabetes melitus tipe-2 di RS. Islam Sukapura tahun 2018. Dari hasil studi ini dapat disimpulkan bahwa proporsi pasien diabetes melitus tipe-2 yang mendapatkan insulin human 41\% (82 orang) dan insulin analog 59\% (118 orang). Tidak ada perbedaan yang bermakna secara statistik maupun klinik efektifitas insulin human dibandingkan insulin analog.

\section{UCAPAN TERIMA KASIH}

Penulis mengucapkan terima kasih kepada bagian rekam medis dan poliklinik penyakit dalam RS. Islam Sukapura karena telah membantu memperoleh data di dalam penelitian ini. Penulis juga mengucapkan terima kasih kepada bagian farmakologi dan terapeutik FKUI-RSCM karena membantu proses analisa dan penyelesaian penelitian ini.

\section{KONFLIK KEPENTINGAN}

Penulis menyatakan tidak memiliki konflik kepentingan, dan tidak ada afiliasi atau koneksi dengan atau dengan entitas atau organisasi apa pun, yang dapat menimbulkan pertanyaan bias dalam diskusi dan kesimpulan naskah.

\section{REFERENSI}

1. World Health Organization. Diabetes di Indonesia. Diabetes Fakta dan Angka. 2016.

2. Pusat Data dan Informasi Kementerian Kesehatan Republik Indonesia. Situasi dan Analisis Diabetes. 2014.

3. Badan Pusat Statistik, Badan Koordinasi Keluarga Berencana
Nasional, Departemen Kesehatan, Macro Internasional. Survei Demografi dan Kesehatan Indonesia 2007. Jakarta; 2008.

4. Baynest HW. Classification, Pathophysiology, Diagnosis and Management of Diabetes Mellitus. J Diabetes Metab. 2015;06(05):1-9.

5. DeFronzo RA. From the Triumvirate to the Ominous Octet: A New Paradigm for the Treatment of Type 2 Diabetes Mellitus. Diabetes. 2009 Apr 1;58(4):773-95.

6. Cersosimo E, Solis-Herrera C, Trautmann M, Malloy J, Triplitt C. Assessment of Pancreatic \& Cell Function: Review of Methods and Clinical Applications. Curr Diabetes Rev. 2014 Mar 31;10(1):2-42.

7. Aslan I, Kucuksayan E, Aslan M. Effect of insulin analog initiation therapy on LDL/HDL subfraction profile and HDL associated enzymes in type 2 diabetic patients. Lipids Health Dis. 2013 Dec 24;12(1):54.

8. Ionut V, Zheng D, Stefanovski D, Bergman RN. Exenatide can reduce glucose independent of islet hormones or gastric emptying. Am J Physiol Metab. 2008 Aug;295(2):E269-77.

9. Mannucci E, Monami M, Marchionni N. Short-acting insulin analogues vs. regular human insulin in type 2 diabetes: a meta-analysis. Diabetes, Obes Metab. 2009 Jan;11(1):53-9.

10. Handelsman $\mathrm{Y}$, Bloomgarden ZT, Grunberger G, Umpierrez G, Zimmerman RS, Bailey TS, et al. American Association of Clinical Endocrinologists and American College of Endocrinology--Clinical Practice Guidelines for Developing A Diabetes Mellitus Comprehensive Care Plan--2015--Executive 
Summary. Endocr Pract. 2015 Apr;21(4):413-37.

11. American Diabetes Association. Executive Summary: Standards of Medical Care in Diabetes--2014. Diabetes Care. 2014 Jan 1;37:S5-13.

12. Machado-Alba JE, Medina-Morales DA. Comparison of the impact of human vs analogue insulins on glycosylated haemoglobin in a population with diabetes mellitus. Int $\mathbf{J}$ Clin Pract. 2016 Dec;70(12):9961002.

13. Auryan S, Itamar R. Gender-specific care of diabetes mellitus: particular considerations in the management of diabetic women. Diabetes, Obes Metab. 2008 May 20;10(12):1135-56.

14. Kementerian Kesehatan Republik Indonesia. Riset Kesehatan Dasar 2013. Badan Penelitian dan Pengembangan Kesehatan. Jakarta: Kementerian Kesehatan Republik Indonesia; 2013.

15. Kasier Permante Washington. Type 2 Diabetes Screening and Treatment Guideline Major Changes as of June 2015. 2015 p. 1-17.

16. Inzucchi SE, Bergenstal RM, Buse JB, Diamant M, Ferrannini E, Nauck M, et al. Management of Hyperglycemia in Type 2 Diabetes, 2015: A PatientCentered Approach: Update to a Position Statement of the American Diabetes Association and the European Association for the Study of Diabetes. Diabetes Care. 2015 Jan 23;38(1):140-9.

17. Medical Development Division Ministry of Health Malaysia. Health

Technology Assessment: Insulin Analogues. Putrajaya, Malaysia; 2012.

18. Yoo HJ, Park KY, Park KS, Ahn KJ, Min KW, Park JH, et al. Safety and
Efficacy of Modern Insulin Analogues. Diabetes Metab J. 2013;37(3):181.

19. Borgquist S, Rosendahl AH, Czene K, Bhoo-Pathy N, Dorkhan M, Hall P, et al. Long-term exposure to insulin and volumetric mammographic density: observational and genetic associations in the Karma study. Breast Cancer Res. 2018 Dec 9;20(1):93. 